\title{
HOMICIDE IN CANADA
}

Bonny Walford

The crime of homicide is regarded as the most heinous of crimes by most members of Canadian society. Society's degree of condemnation is reflected in the severity of the sanctions and punishments for this crime.

There are two divisions of murder and one of manslaughter in Canada. First degree murder is one that is planned and deliberate; one in which the victim is a police officer, prison guard, hijack victim, sexual assault victim, or one committed by a person previously convicted of either first or second degree murder. Second degree murder is defined as all murder that is not first degree (i.e. not premeditated). Manslaughter is all culpable homicide that is not murder or infanticide, i.e. there is a lack of intent to kill (Government of Canada 1985: 222). The sentence for first degree murder is life with a minimum of twenty-five years before parole. The sentence for second degree murder is life with a minimum of ten years before parole. Sentences for manslaughter range from eighteen months to life depending on the perceived severity of the crime, the most common sentences being from three to five years with parole eligibility after one-sixth of the sentence has been served. Most prisoners serve one-third to half the sentence before release.

There is a great deal of confusion in Canada regarding the degree of homicide that has occurred in any given case and the amount of punishment that is appropriate. The various degrees of homicide may be interpreted very 
differently and sentences often do not fit the crime. Second degree murder and manslaughter are especially ambiguous since both involve no intent to kill. In fact, the only difference between the two occurs when the police charge a person with one or the other as they chose, and they are choosing to charge most offenders with first or second degree murder when they are guilty of second degree murder, or second degree murder when they committed manslaughter only.

Statistics Canada's report for 1987 demonstrates this. Between 1965 and 1971, while the death penalty was still in effect, police charged only six per cent with first degree murder, twenty-eight per cent with second degree, and the vast majority, sixty-five per cent, with manslaughter. Between 1977 and 1988, when the death penalty was replaced with the twenty-five year minimum sentence, police charged thirty-eight per cent with first degree murder, fifty-two per cent with second degree murder (almost double), and only nine per cent with manslaughter. This does not mean that more people were committing first and second degree murder and fewer people were committing manslaughter. It does mean that legislators and other agents of social control decided "to get tough" in exchange for parting very reluctantly with the death penalty. Police and lawmakers found the public willing to condemn many more accused of first degree murder once the death penalty was repealed. So, although many people did not agree with "an eye for an eye," they were willing to condemn accused to at least twenty-five long, horrendous years in prison. So, instead of making the law more lenient or humane as it would at first appear, laws and sentences became far more severe for over eighty per cent of persons involved in homicide. The legal attitude seems to be, "We will take away the death penalty and appear to be more humane, but we will really nail all killers to the cross!"

Why have lawmakers gotten so strict with persons accused of homicide? What explains why police are charging more people with first degree and second degree murder and fewer people with manslaughter? Obviously, 
it is not just a "trade off" for the death penalty. There seems to be some confusion on all parts. Lawmakers are ill informed and confused as to definitions of various forms of homicide and the sentences that are appropriate for each. It appears that they are assuming that police know. The public, while condemning all homicide, know very little about the distinctions between first and second degree murder and manslaughter and seem to assume that lawmakers and police know. What actually happens is that legislators and police take advantage of the public's ignorance and fear of "cold-blooded" and "depraved" killers, as portrayed in the media. The public does not realize that lawmakers are encouraging police to charge most people with first and second degree murder and fewer people with manslaughter. They are ignorant of the change that has occurred following the abolition of capital punishment in 1976 and are easily convinced by police that murders are now "getting off easy" compared to before, when in fact the very opposite is true. So, not only are lawmakers and police exercising more vengeance than ever before, they are deliberately influencing the public to believe that killers are escaping just punishment. Hence the public demands the stiffer penalties which legislators have already implemented.

The confusion and ambiguity in the distinctions between second degree murder and manslaughter are even greater than between first and second degree murder. This allows police to charge most people with second degree murder as they chose, and based on the figures given above, it is clear that they almost always choose second degree if they do not feel they can "get" an accused for first degree. Lawmakers have thus given police greater power of vengeance, which I believe was done in order to appease police who were very strongly in favour of the death penalty. (Often police tell an accused that it is too bad s/ he will not hang or "fry" with much hostility and bitterness in their voices).

By charging a degree higher than the crime merits, police know that the chance of getting an accused to plead 
guilty to a lesser charge is very great; so if they want to "get" a person on second degree without the time and expense of a trial, they simply charge the person with first degree and offer to drop it to second degree if the person. pleads guilty. Most people so fear the twenty-five year penalty that they plead guilty to second degree even though they know (and in most cases the police know) that the homicide was manslaughter. This happened to many, many women I know, including myself. Legally this is called plea bargaining, but what it really is is the worst form of coercion, intimidation, and blackmail all rolled into one. By forcing people to plead guilty to second degree murder, police and lawmakers automatically take away their right to a fair and fully informed trial, as well as condemning them to a minimum of ten years in prison when their crime merited perhaps one to three years. Without a trial, there can be no hope of justice. Without a trial, no one gets to hear the all important circumstances which led up to the crime.

When capital punishment was in force, police did not have such power over offenders. They could not press first degree unless the crime clearly was first degree because they knew that few juries would be willing to condemn a person to death. But juries do not seem to have the same aversion to sending a person away for twenty-five years, and the police use this to their advantage. They prey on the person's tremendous fear of twenty-five incredibly long years behind bars to obtain a guilty plea to second degree. This is aided and abetted by Crown attorneys and judges who appreciate the arrangement because if everyone had trials, courts would be overworked and over budgeted. It is not known how many people were thus forced to plead guilty to second degree murder since everyone in prison is registered as "convicted", even if they pleaded guilty without benefit of a trial. Police could not thus overcharge when capital punishment was law; then they had to assess cases more justly.

The public is constantly exposed to the murder stereotype through the media. It is not unusual for people 
coming into prison and meeting "murderers" to be shocked and exclaim, "My God, you are just like normal people...I expected, I mean..., I thought...." They are surprised and confused because the majority of lifers are no different from average people on the street. Because newspapers and media, in general, sensationalize homicides and very rarely give a profile of the accused or the circumstances of her/ his crime (while at the same time extolling the virtues of the deceased), the public receives a very biased view of the crime and the perpetrator. So the stereotype continues.

This is compounded by the fact that due to plea bargaining (which you must remember is really a means to threaten an accused with first degree so $\mathrm{s} /$ he pleads guilty to second degree) there are relatively few homicide cases which go before a jury. If an accused manages to get a trial, there is a strong possibility that the stereotype will cease to exist for those twelve people on the jury.

How can all the confusion surrounding the crime of homicide be remedied? I propose a very simple and fair solution. If lawmakers got rid of the categories of homicide and simply charged every accused with "homicide," it would eliminate the difficulties of the police overcharging. This would have to be coupled with several other changes. Either a jury or panel of judges would have to assess each case. The accused could give full account of herself or himself and the circumstances of the crime so the degree of deviance could be clearly and fairly established. Also, instead of the horrendous minimum and life sentences, I propose a variable scale of, for instance, one to fifty years with parole eligibility after serving one-third of the sentence. I suggest that this provides for all degrees of guilt and corresponding degrees of punishment. It is not right to squeeze four hundred cases per year into the existing two sentence brackets of ten to twenty-five years and twenty-five minimum. Many, many cases really merit sentences of five years or less. Futhermore, every person accused should be guaranteed an experienced homicide lawyer in order to receive a fair chance at the trial.

These changes would appear to require much court 
time and money. However, it must be remembered that the cost of keeping a person in prison is $\$ 65,000$ per year. With the variable scale of sentencing suggested here, I am confident that most of those convicted of homicide would. be sentenced to serve less than one-third of the combined time currently served by lifers. This would save the government many tens of millions of dollars: enough to build more courts, to hire more judges, and so forth. Millions would be left over to put into rehabilitation, youth centres, counselling facilities, job creation for ex-convicts, and post-release aid. So many positive things could be done with the money saved. It would be a positive reflection on the society which sees fit to implement them.

\section{Reference}

Government of Canada (1985) Martin's Annual Criminal Code. Canada Law Book Inc. 